\title{
ГОСПОДАРСЬКЕ ПРАВО
}

УДК 349.41(045)

\author{
Н. В. Жмур, \\ кандидат юридичних наук \\ ORCID ID: https://orcid.org/0000-0001-5462-4482
}

М. М. Лавренчук,

здобувач вищої освіти першого (бакалаврського) рівня

\section{ТРАНСФОРМАЦІЯ СИСТЕМИ КАДАСТРОВОГО ОБЛІКУ: ВІД ЧАСІВ НЕЗАЛЕЖНОСТІ УКРАЇНИ ДО СЬОГОДЕННЯ}

\author{
Національний авіаційний університет \\ проспект Любомира Гузара, 1, 03680, Київ, Україна \\ E-mails: nataliia.zhmur@npp.nau.edu.ua,5253310@stud.nau.edu.ua
}

\begin{abstract}
Мета: комплексно дослідити історичні аспекти розвитку системи кадастрового обліку земельних ділянок в Україні. Методи дослідження: документального аналізу $i$ синтезу, порівняльного аналізу, історичний, пізнавально-аналітичний та ін. Результати: проведено історичний аналіз становлення і розвитку системи кадастру на території України, а також досліджено теоретичні положення щцодо ведення земельного кадастру, розкрито його поняття та цілі. Обговорення: з'ясовано нормативне закріплення земельного кадастрового обліку $в$ законодавстві Украӥни, практичний аспект земельного кадастру, а також окреслено перспективи вдосконалення законодавства щодо ведення земельного кадастру в Украйні.
\end{abstract}

Ключові слова: законодавство; земельний кадастр; кадастровий облік; земельна ділянка; земельна реформа.

Постановка проблеми та її актуальність. Із часів незалежності України, і початку земельної реформи, розпочався процес приватизації, купівлі-продажу, оренди земельних ділянок громадянами держави. Після десятиліть мораторію на продаж землі, в українському законодавстві розпочинається новий етап земельної реформи - впровадження ринку землі, що регламентуватиметься Законом України «Про внесення змін до деяких законодавчих актів України щодо умов обігу земель сільськогосподарського призначення», який був ухвалений Верховною Радою України 31 березня 2020 року, а набирає чинності з 1 липня 2021 року [8].

Наразі в умовах вдосконалення господарського механізму перед державою стоїть завдання вирішити питання щодо покращення управління земельними ресурсами, оцінки земель, вдосконалення існуючих технологій ведення земельно- го кадастру і впровадження нових, а також використання земельно-кадастрової облікової інформації. Тому актуалізація та систематизація геопросторових даних, а також створення нових систем для покращення ефективності роботи кадастрового обліку є першочерговими завданнями.

Аналіз останніх досліджень і публікацій. Питання розвитку земельного кадастру в генезисі років досліджували такі українські та зарубіжні науковці в галузі земельного та екологічного права, як B.I. Андрейцев, Г.І. Балюк, А.А. Варламова, Ю.О. Вовк, I.I. Каракаш, П.В. Клюшина, Т.Г. Ковальчук, М.В. Краснова, П.Ф. Кулинич, В.Л. Мунтян, В.К. Послов, Н.І. Титова, А.С. Циганкова, Ю.С. Шемшученко, В.С. Шелестов, М.В. Шульга, В.3. Янчук та інші. 
Мета статті полягає в комплексному дослідженні реалізації права громадян на земельну ділянку, доступу до публічної інформації, вивченні історичних етапів становлення і розвитку законодавства у сфері ведення і регулювання земельного кадастру.

Виклад основного матеріалу. В умовах вдосконалення господарського механізму в державі особливе значення мають питання управління земельними ресурсами, впровадження нових технологій ведення земельного кадастру, оцінки земель і використання земельно-кадастрової інформації.

Так як законодавчо поняття «кадастр» не закріплено, для його формування необхідно розглянути думки деяких вчених.

Наприклад, енциклопедичний словник Ф.А. Брокгауза та I.А. Ефрона 1890-1907 pp. вживає поняття «кадастр» як таке, що походить iз середньовічного латинського «catastrum», що означає реєстр душ, які підлягають оподаткуванню. В тлумачному словнику російської мови в редакції від Д.М. Ушакова (Т. 1, 1935 р.), термін «кадастр» означає сукупність розроблених відомостей про об'єкти оподаткування [1, с. 95].

Звертаючись до практики $\mathrm{OOH}$, а також Міжнародної федерації геодезистів (FIG) у Богорської (Bogor, Індонезія, 18-22 березня 1996 р.), а потім і у Бафертської (Bathurst, Австралія, 22 жовтня 1999 р.) деклараціях, можна знайти таке визначення кадастру - це заснована на земельних ділянках (парцелах) сучасна земельна інформаційна система, що містить записи про права на нерухомість (наприклад, права, обмеження і зобов'язання) [10, с. 42].

Радянський енциклопедичний словник у редакції А.М. Прохорова (1984 р.) трактує «кадастр» як систематизований звід відомостей, який формується шляхом періодичних або безперервних спостережень над відповідним об'єктом.

Після проголошення незалежності України порядок ведення, призначення і зміст земельного кадастру регламентується Земельним кодексом України [5] та постановою Кабінету Міністрів України від 12 січня 1993 р. № 15
«Про порядок ведення державного земельного кадастру» в редакції від 21 червня 2004 р.

Поняття земельного кадастру регламентується статтею 1 Закону України «Про державний земельний кадастр» [13] - це єдина система відомостей про землі, які розташовані в межах державного кордону України, а також дані про якісну характеристику земель, їх оцінку, цільове призначення, про розподіл земель між власниками і користувачами.

Л.П. Фоміна зазначає: «земельний кадастр це юридично значима інформаційна система, яка необхідна для розвитку земельного обороту, а також планування і контроль раціонального використання земельних ресурсів в інтересах суспільства відповідно до його потреб» [14, с. 116].

Об'єктом земельного кадастру є земля не лише як природний ресурс, але й як засіб промислового виробництва. Деякі зарубіжні вчені схиляються до того, що об'єктом земельного кадастру є сама інформація про земельну ділянку, «докладна інформація на рівні індивідуальних ділянок» $[11$, с. 7]. На нашу думку, у даній ситуації інформація виступає саме предметом здійснення земельного кадастрування, основним засобом функціонування кадастрової системи взагалі. У зарубіжних країнах, таких як Німеччина, Швеція, ведеться багатоцільовий кадастр, і в такому випадку об'єктом кадастру виступає об'єднання і земельно-майнового комплексу, i інформації про нього, а також інформації про нерухомі об'єкти, які знаходяться на цій ділянці землі.

Розвиток кадастру в Україні характеризувався п'ятьма основними етапами, так званими земельними реформами, які суттєво змінювали форми, зміст та принципи ведення кадастрового обліку земель, але при всіх історичних етапах розвитку земельний кадастр здійснювався 3 метою оподаткування: перший етап - правління Київської Русі; другий етап часи гетьманщини; третій етап - українські землі у складі Австро-Угорської імперії; четвертий етап - Україна у складі СРСР; п'ятий етап часи незалежності України.

Дивлячись на такий розподіл можна зробити висновок, що призначення кадастру, а також йо- 
го структура мінялися в залежності від політико-економічної ситуації.

Сьогодні, відповідно до ст. 194 Земельного кодексу України, призначенням державного земельного кадастру є забезпечення необхідною інформацією органів державної влади та органів місцевого самоврядування, заінтересованих підприємств, установ і організацій, а також громадян 3 метою регулювання земельних відносин, раціонального використання та охорони земель, визначення розміру плати за землю i цінності земель у складі природних ресурсів, контролю за використанням і охороною земель, економічного та екологічного обгрунтування бізнес-планів та проектів землеустрою [5].

Найдавнішим кадастровим документом вважається перепис земель Київської Русі при хані Батиї (1245 р.) та хані Менгу (1273 р.), хоч проводився перепис підкорених земель. Це впроваджувалося для визначення розміру данини, яка, очевидно, залежала від кількості орних земель, які оброблювали люди. Варто зауважити, що у володіннях кожного князя Київської Русі формувалися так звані «писцеві» книги, де фіксувалися межа, місцезнаходження, площа, якість грунту, до чиїх володінь належить, адже виникала потреба для правильного обкладання податками i повинностями землевласників [2, с. 177]. Вказані книги слід вважати початком запровадження в Україні земельного кадастру.

Із розпадом Київської Русі західна частина українських земель переходить під владу великого литовського князя, який для встановлення порядку в земельних відносинах у 1528 році організував перепис землевласників, де зазначалася кількість дворів у кожному землеволодінні та його розміри.

Гетьман України Данило Галицький у 1729 р. i до 1731 року проводив інвентаризацію всіх землеволодінь, поділивши землі на такі категорії: вільні, спірні, міські, рангові, церковні та надані за певні заслуги перед державою. Система обліку земельних ділянок набирає обертів у розвитку, адже уся проведена робота документується [2, с. 180].

Наприкінці 18 століття, коли частина земель перейшли до складу Австро-Угорщини, а ча- стина до Російської імперії, це не завадило місцевим представникам влади і далі займатися обліком земельних ділянок і на основі цих кадастрових даних розробити принципи оподаткування. Селяни мали право 70\% прибутку залишати собі, 12\% - віддавали державі та $18 \%$ панові.

Після появи в 1881 році Іпотечної системи, а згодом i Поземельних книг, почалося впровадження реєстрації земельних ділянок, у поземельних книгах реєструвалися ім'я власника, права власності, договори, заповіти, сервітути та інші права, застава, заставні, а також вносилися відомості про місцезнаходження, склад, територію, систему оподатковування і вартість об'єкту реєстрації [1, с. 98]. Ці дані використовувалися для встановлення податку на землю. Крім таких поземельних книг дані про ділянку землі, про власника знаходили своє відображення і в сільських реєстрах, платіжних книгах, які видавалися на село, книгах сходу села тощо.

У часи, коли Україна знаходилася у складі СРСР, проводилися масові процеси націоналізації земель, заводів та фабрик, а приватна власність поступово ліквідовувалась. Ці кадастри та облікові книги земель грунтувалися на єдиних правилах і вимогах союзу, і тоді кадастр представляв собою інструмент централізованого господарсько-економічного управління різними регіонами й імперією загалом.

Визначними для України підзаконними актами, які приймалися владою в СРСР, є прийнята в 1954 році Постанова Ради Міністрів СРСР «Про єдиний державний земельний облік», у якій передбачалося складати сільськогосподарські карти для планування i обліку земель [3].

У 1962 році та в наступні роки на земельних ділянках проводилися оціночні роботи, коли землю оцінювали як природний ресурс, засіб виробництва в сільському господарстві, а також продуктивність земель, ефективність використання i дохід, який отримується 3 одиниці площі. Цей процес отримав назву «економічна оцінка земель».

Після набуття Україною незалежності, а саме впровадженням у дію в 1992 році Земельного кодексу України, ведення земельного кадастру 
входить до повноважень місцевих і державних органів влади. Тоді ж вводилося в дію картографічно-планове кадастрування земельних ділянок, коли для складання карт і планів використовувалися топогрфічні карти, а в разі їх відсутності - аеро- і космічних зйомок. Регламентованими стали дії щодо порядку ведення земельного кадастру, а також фінансування системи обліку земельних ділянок.

Наразі в Україні розпочато підготовку до відкриття ринку землі, проводяться масштабні ортофотозйомки усіх земельних ділянок на території держави, що дозволить повністю оновити кадастрову карту земель, також детально описуються і документуються усі адміністративно-територіальні межі; проводиться реєстрація земельних ділянок.

Вважаємо, що для успішного сучасного функціонування землі в цивільному обороті, ведення і діджиталізація системи держгеокадастру $\epsilon$ одним із основних аспектів захисту прав суб'єктів земельних правовідносин.

Процес покращення кадастрового обліку вже стартував одночасно 3 прийняттям 13 квітня 2020 року Закону України «Про національну інфраструктуру геопросторових даних», який набув чинності 1 січня 2021 року [9]. Перше і найголовніше, чому цей Закон вважають революційним, то завдяки цьому нормативноправовому акту проводяться роботи по створенню єдиного Геопорталу кадастрів та геопросторових даних, користування яким буде безкоштовним, а інформація стане повністю відкритою і оновлюватиметься в режимі реального часу. Це дасть можливість об'єднати інформацію про різні об'єкти інфраструктури, мережі комунікацій та бази даних в одному місці, що забезпечить систематизацію інформації про геопросторові дані й метадані та отримання якісної аналітики.

Наприклад, за офіційними даними Державної служби України з питань геодезії, картографії та кадастру, які опубліковані на Урядовому порталі, станом на кінець грудня 2020 року до Державного земельного кадастру внесені відомості про 22,5 млн земельних ділянок, зокрема 15,1 млн - ділянки землі сільськогосподарського призначення [12].
Також внесені відомості про межі 8935 адміністративно-територіальних одиниць (за заявами місцевих органів влади). До кадастрових реєстрів надійшло 45,6 тис. заяв про реєстрацію земельних ділянок, зареєстрованими залишилися 39,0 тис земельних ділянок [12].

Звернувши увагу на опубліковані статистичні дані за січень 2021 року, то на сьогоднішній день до земельного кадастру додані відомості про 500 тис. земельних ділянок, відображені дані про межі 95 адміністративнотериторіальних одиниць, а до реєстрів земельних ділянок надійшло близько 7,5 тис заяв про реєстрацію ділянок землі [12].

Порівнюючи дані Держгеокадастру по вказаних критеріях, можна зробити висновок, що до прийняття вказаного вище Закону усі показники були нижчі на 1,3\%. Це означає, що відповідними державними органами проводиться повна підготовка до відкриття ринку землі, адже перед його запровадженням повинна бути повністю актуалізована інформаційна система кадастрового обліку, а також державна система реєстрації прав на нерухомість, особливо для земельних ділянок сільськогосподарського призначення.

Щодо основних нововведень, які чекають кадастрову систему після набрання чинності закону про ринок землі, це: завдяки Державному земельному кадастру буде проводитися перевірка покупця ділянки на предмет можливості її придбання в певному розмірі (вводиться обмеження щодо загальної площі земельних ділянок сільськогосподарського призначення, які вправі набувати у власність одна особа). Завдяки оціночним даним, які складатимуться 3 аналізу грунтів за різними параметрами, Держгеокадастром буде встановлюватися ціна земельної ділянки [12].

Зараз одним із найбільш актуальних питань щодо ведення земельного обліку $\epsilon$ запровадження в Україні Єдиної кадастровореєстраційної платформи, функцією якої була б реєстрація об'єктів нерухомості та прав на них, а також земельних ділянок. Це сприяло б ефективності системи оподаткування, а також прозорості ринку землі, створенню привабливих умов для інвестицій і забезпечення їх захисту. Вважаємо, що перш за все необхідно створити окремий підзаконний акт, який регулював би 
порядок внесення відомостей у реєстр, окреслював коло відповідальних осіб, а також встановлював стандарти по внесенню інформації, щоб вона не залишалася недостатньою чи неповноцінною.

Інформаційна база державного кадастрового обліку земель повинна містити відомості в графічному і текстовому (реєстр будинків і споруд, реєстр територіальних зон, реєстр земельних ділянок, реєстр власників і користувачів земельних ділянок тощо) вигляді 3 даними кадастрового обліку земельних ділянок й іншого нерухомого майна та забезпечувати узагальнення цих даних за встановленою формою [11, с. 198].

Вказана інтегрована платформа повинна пов'язуватися із реєстрами оцінки землі та земельних покращень, права власності. Завдяки цьому буде впроваджено ефективне планування традиційного землекористування та урбанізованих територій, оцінки і ступеня використання земель, що стимулюватиме їх ефективне використання і охорону. Наприклад, земельний кадастр у Польщі пов'язаний із реєстром земельних ділянок i реєстром оцінки, які ведуть Міністерство фінансів та Міністерство юстиції. У Німеччині реєстри оцінки нерухомості та нерухомості на земельних ділянках з 2010 року інтегруються в єдину кадастрову систему ALKIS, яка, своєю чергою, тісно інтегрується 3 базою геодезичних даних AFIS та топографічних ATKIS [3].

Доцільною пропозицією для покращення роботи кадастрової системи є запровадження карт і малюнків у форматі 3D. Важливим це буде для функціонального погляду на кадастр майбутнього, адже розвиток гірських рекреаційних зон та урбанізація територій, вимагає, з одного боку, визначення положення i розмірів підземних споруд (тунелів, транспортних розв'язок, паркінгів, об'єктів сфери обслуговування тощо), 3 іншого боку, будівництва гірськолижних трас, туристичних маршрутів тощо.

Вважаємо, що доцільним для кращого функціонування кадастрових перевірок необхідно впровадити систему моніторингу земельних ресурсів і систематизувати іiі для пошуку інформації щодо угод купівлі-продажу землі. Ця система повинна поєднуватися з базою речових прав Міністерства юстиції України для покращення відслідковування кількості гектарів земельних ділянок, які зареєстровані на одну особу, а також для ефективного управління землями органами територіальної громади [4].

Важливим аспектом дотримання усіх встановлених норм і стандартів, а також контроль за якісним впровадженням нововведень $є$ встановлення юридичної відповідальності за проступки у сфері обліку земельних ділянок і кадастру.

Громадяни і юридичні особи, винні в правопорушенні, повинні нести відповідальність відповідно до законодавства України. Таким чином, у випадках порушення принципів ведення державного земельного кадастру до суб'єктів правопорушень у даній сфері будуть застосовуватися усі відомі правовій науці види юридичної відповідальності, кожний з яких має свої особливості, і на даному етапі розвитку законодавства про державний земельний кадастр проблеми реалізаціі.

Наразі в українському законодавстві немає чітко сформованого переліку проступків або ж навіть злочинів у сфері впорядкування і ведення земельного кадастру, тому, ми вважаємо, що для дотримання органами влади і місцевого самоврядування своїх повноважень, а також для добросовісного користування землею фізичними та юридичними особами необхідно прийняти певний нормативно-правовий акт про грошову чи майнову відповідальність за порушення у даній сфері, і щоб виручені кошти йшли у створений фонд для покращення, можливо, родючості земель, чи для вдосконалення інформаційної системи кадастрового обліку.

Стає зрозуміло, що сьогодні перед аграрною економікою стоїть ряд невирішених проблем перед запровадженням ринку землі, проте варто пам'ятати, що саме в руках Держгеокадастру знаходиться розпорядження всіма землями на території України. Тому актуалізація та систематизація геопросторових даних, а також створення нових систем для покращення ефективності роботи кадастрового обліку $є$ одним із першочергових завдань. А для цього слід впровадити технічні інструменти для контролю за обмеженнями щодо концентрації земель у влас- 
ності громадян та юридичних осіб, створити систему моніторингу земельних відносин, ввести в експлуатацію національний Геопортал, ухвалити методику грошової оцінки земель.

Висновки. Аналіз теоретичних положень про державне управління земельними ресурсами, здійснення його функцій, а також норм діючого земельного законодавства, що регулюють суспільні відносини в даній сфері, дозволяє зробити деякі висновки про роль державного земельного кадастру і перспективи його подальшого розвитку.

По-перше, необхідно розробити і сформувати план втілення в життя зазначених вище нововведень і положень, аби правова система змогла забезпечити ведення державного земельного кадастру як функції державного управління, реалізацію всіх економічних, соціальних та інших цілей. Насамперед, це стосується фінансування передбачених законодавством заходів, а також використання інших засобів, метою яких є створення багатоцільової земельно-кадастрової системи, яка б відповідала всім сучасним вимогам.

По-друге, будь-яка взаємодія управлінських функцій, пов'язаних із забезпеченням повноти змісту державного земельного кадастру або застосування його даних у ході державних заходів, повинна грунтуватися на правових нормах. «Положення, відповідно до якого в державному управлінні потрібно виходити із права, виробленого суспільством на певному етапі його розвитку, становить важливий правовий (i разом $з$ тим ідеологічний і моральний) імператив, що адресується суспільством державі як керуючій системі - бути правомірним у всіх своїх акціях і проявах». Тому в законодавстві, що регулює порядок ведення державного земельного кадастру, повинен бути закріплений науково розроблений механізм взаємодії вищевказаних функцій.

\section{Jimepamypa}

1. Кучеренко C.I., Анопрієнко Т.В. Аналіз сучасного стану кадастрової оцінки земельних ділянок. Системи обробки інформащії. 2016. № 1 (138). C. 94-99.
2. Горлачук В.В., Песчанська I.M., Скороходов В.А. Земельний менеджмент: навч. посіб. Київ: ВД «Професіонал», 2006. 192 с.

3. Застосування ГІС-технології у сфері земельного кадастру та землеустрою. URL: http://www.zisforum.org.ua/index.php?topic $=242.0$ (дата звернення 27.02.2021).

4. Земельний кодекс України: наук.-практ. коментар / Андрейцев B.I., Балюк Г.І., Гетьман А.П. та ін.; за заг. ред. В.І. Семчика; Ін-т держави i права ім. В.М. Корецького НАН України, Київ. ун-т права. 2-е вид., перероб. і допов. Київ: Вид. дім «Ін Юре», 2004. 745 с.

5. Земельний кодекс України: станом на 01 жовт. 2017 p. URL: http://rada.gov.ua/laws/ show/ (дата звернення 27.02.2021).

6. Конституція України. URL: http://zakon4. rada.gov.ua/laws/show/254к/96-вр (дата звернення 21.02.2021).

7. Носік В.В. Конституційні засади реалізації права власності на землю в Україні. Актуальні питання приватизаиії та оиінки земель: зб. наук. праць / за ред. Б.А. Семененка. Суми: ВВП «Мрія-1», 1999. С. 12-16.

8. Про внесення змін до деяких законодавчих актів України щодо умов обігу земель сільськогосподарського призначення: Закон України від 31 бер. 2020 p. № 552-IX. Статус: не набрав чинності. URL: https://ips. ligazakon. net/ document/ view/ T200552?an=73 (дата звернення 18.02.2021).

9. Про національну інфраструктуру геопросторових даних: Закон України від 13 бер. 2020 p. № 554-IX. URL: https://zakon.rada.gov.ua/ laws/ show/ 554-20\#Text (дата звернення 22.01.2021).

10. Сидоренко В.Н. Земельный кадастр: зарубежный опыт ведения. Экологическое право. 2003. № 4. C. 41-44.

11. Управління земельними ресурсами: підручник / Горлачук В.В., В'юн В.Г., Песчанська I.M., Сохнич А.Я. та ін.; за ред. Горлачука В.В. 2-ге вид., випр. і переробл. Львів: Магнолія плюс; видавець СПД ФО Піча В.М., 2009. $443 \mathrm{c}$.

12. Урядовий портал. Ведення Державного земельного кадастру: актуальні показники. URL: https://www.kmu.gov.ua/news/vedennya- 
derzhavnogo-zemelnogo-kadastru-aktualnipokazniki-22-12-20. Назва 3 екрана. Дата публікації: 22 груд. 2020 р. (дата звернення: 26.01.2021).

13. Про Державний земельний кадастр: Закон України від 07 лип. 2011 р. № 3613-VI. Oфіuійний вісник Украӥни. 2011. 15 серп. № 60. С. 64. Ст. 2405.

14. Фомина Л.П. Государственное регулирование и право собственности на землю в сельском хозяйстве. Москва, 1996. 263 с.

\section{References}

1. Kucherenko Je.I., Anoprijenko T.V. Analiz suchasnogo stanu kadastrovoi' ocinky zemel'nyh diljanok. Systemy obrobky informacii'. 2016. № 1 (138). S. 94-99.

2. Gorlachuk V.V., Peschans'ka I.M., Skorohodov V.A. Zemel'nyj menedzhment: navch. posib. Kyi'v: VD «Profesional», 2006. 192 s.

3. Zastosuvannja GIS-tehnologii' u sferi zemel'nogo kadastru ta zemleustroju. URL: http://www.zisforum.org.ua/index.php?topic $=242.0$ (data zvernennja 27.02.2021).

4. Zemel'nyj kodeks Ukrai'ny: nauk.-prakt. komentar / Andrejcev V.I., Baljuk G.I., Get'man A.P. ta in.; za zag. red. V.I. Semchyka; Int derzhavy i prava im. V.M. Korec'kogo NAN Ukrai'ny, Kyi'v. un-t prava. 2-e vyd., pererob. i dopov. Kyi’v: Vyd. dim «In Jure», 2004. 745 s.

5. Zemel'nyj kodeks Ukrai'ny: stanom na 01 zhovt. 2017 r. URL: http://rada. gov. ua/ laws/ show/ (data zvernennja 27.02.2021).

6. Konstytucija Ukrai'ny. URL: http://zakon4. rada.gov.ua/laws/show/254k/96-vr (data zvernennja 21.02.2021).

7. Nosik V.V. Konstytucijni zasady realizacii' prava vlasnosti na zemlju v Ukrai'ni. Aktual'ni pytannja pryvatyzacii' ta ocinky zemel': zb. nauk. prac' / za red. B.A. Semenenka. Sumy: VVP «Mrija-1», 1999. S. 12-16.

8. Pro vnesennja zmin do dejakyh zakonodavchyh aktiv Ukrai'ny shhodo umov obigu zemel' sil's'kogospodars'kogo pryznachennja: Zakon Ukrai'ny vid 31 ber. 2020 r. № 552-IX. Status: ne nabrav chynnosti. URL: https://ips.ligazakon.net/ document/view/T200552?an=73 (data zvernennja 18.02.2021).

9. Pro nacional'nu infrastrukturu geoprostorovyh danyh: Zakon Ukrai'ny vid 13 ber. 2020 r. № 554-IX. URL: https://zakon.rada.gov. ua/ laws/ show/ 554-20\#Text (data zvernennja 22.01.2021).

10. Sidorenko V.N. Zemel'nyj kadastr: zarubezhnyj opyt vedenija. Jekologicheskoe pravo. 2003. № 4. S. 41-44.

11. Upravlinnja zemel'nymy resursamy: pidruchnyk / Gorlachuk V.V., V'jun V.G., Peschans'ka I.M., Sohnych A.Ja. ta in.; za red. Gorlachuka V.V. 2-ge vyd., vypr. i pererobl. L'viv: Magnolija pljus; vydavec' SPD FO Picha V.M., 2009. $443 \mathrm{~s}$.

12. Urjadovyj portal. Vedennja Derzhavnogo zemel'nogo kadastru: aktual'ni pokaznyky. URL: https://www.kmu.gov.ua/news/vedennyaderzhavnogo-zemelnogo-kadastru-aktualnipokazniki-22-12-20. Nazva $\mathrm{z}$ ekrana. Data publikacii': 22 grud. 2020 r. (data zvernennja: 26.01.2021).

13. Pro Derzhavnyj zemel'nyj kadastr: Zakon Ukrai'ny vid 07 lyp. 2011 r. № 3613-VI. Oficijnyj visnyk Ukrai'ny. 2011. 15 serp. № 60. S. 64. St. 2405.

14. Fomina L.P. Gosudarstvennoe regulirovanie i pravo sobstvennosti na zemlju v sel'skom hozjajstve. Moskva, 1996. 263 s. 


\title{
N. Zhmur, M. Lavrenchuk \\ TRANSFORMATOIN OF THE CADASTRE SYSTEM: SINSE THE INDEPENDENCE OF UKRAINE TO THE PRESENT
}

\author{
National Aviation University \\ Liubomyra Huzara Avenue, 1, 03680, Kyiv, Ukraine \\ E-mails: nataliia.zhmur@npp.nau.edu.ua,5253310@stud.nau.edu.ua
}

Purpose: comprehensively study the historical aspects of the land plots cadastral system development in Ukraine. Research methods: documentary analysis and synthesis, comparative analysis, historical, cognitive-analytical, etc. Results: carried out a historical analysis of the becoming and development of the cadastre system on Ukraine`s territory, and the theoretical provisions for maintenance of the registry has also been studies, its concepts and purposes are revealed. Discussion: clarified the normative consolidation of land cadastral accounting in the legislation of Ukraine, the practical aspect of the land cadastre maintaining in Ukraine.

Since the independence of Ukraine, and the beginning of land reform, the process of privatization, purchase and sale, lease of land sales, a new stage of state has begun. After decades or moratorium on land sales, a new stage of land reform is beginning in Ukrainian legislation - the introduction of the land market, which will be regulated by the Law of Ukraine "On amendments to certain legislative acts of Ukraine on agricultural land circulation», adopted by Verkhovna Rada of Ukraine on March 31, 2021 year, and comes into force on July 1, 2021.

Currently, in the conditions of improving the economic mechanism, the state faces the task of resolving the issue of improving land management, land valuation, improvement of existing technologies of land cadastre and introduction of new ones, as well as the use of the land cadastral accounting information. That's why, the actualization and systematization of geospatial data, as well as establishment of new systems for improving cadastral system officiency is first priority task.

Keywords: legislation; land cadaster; cadastral accounting; land plot; land reform. 